\title{
EVALUAREA ACCESULUI POPULATIEI DEFAVORIZATE, INCLUSIV ETNIA RROMĂ, LA SERVICIILE PUBLICE DE SĂNĂTATE
}

\section{Ghinescu Minerva ${ }^{1}$}

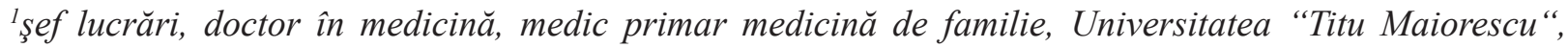
Bucureşti, Facultatea de Medicină

adresa de corespondență: Buftea, aleea Şcolii nr 2-4, județul Ilfov, cod 70000, email ghinescu_minerva@yahoo.com

Title: The evaluation of the access of disadvantaged population, including Rroma ethnics, to the public health services

Abstract: The object of this paper is to present the results of the research in the field of community assistance in the Ilfov district. The practical application and the resulted analysis demonstrates the socio-medical utility of this work.

Through this research, I wanted to offer informations, recommendations and a practical model - the community health team - as a result of evaluating the health conditions, community health services and degree of access/satisfaction of the disadvantaged population including Rroma ethnics. This model and the recommendations can be used by healthcare providers, decision-makers in the governmental/local sectors for improving the health conditions, access and quality of medical services for the disadvantaged communities; Equal treatment and a non-discriminatory attitude will be insured in day-to-day practice in the relations with Rroma patients.

Key words: evaluation, access, disadvantaged population, Rroma ethnics, interview.

Cuvinte cheie: evaluare, acces, populatie dezavantajata, rromi, interviu.

\section{Introducere}

\section{a. CONTEXT - MOTIVAȚIE}

Situația socio-economică a rromilor este apreciată ca fiind una marcată de sărăcie (venituri reduse, condiții de locuit inadecvate, alimentație deficitară, condiții igienice precare, lipsa unui venit permanent, acces greu la serviciile de sănătate, educație deficitară) și de cultura sărăciei (valori, atitudini, cunoștințe și practici, modele de comportament și stil de viață) care perpetuează sărăcia.

Există o diferență în ceea ce privește identificarea cauzelor: reprezentanții etniei rrome văd aceste cauze ca ținând de atitudini discriminatorii care implică societatea extinsă, în timp ce reprezentanții instituțiilor de sănătate atribuie comunităților dezavantajate, inclusiv etnia rromă, responsabilitatea pentru condițiile în care se află.

Pornind de la aceste două ipoteze de lucru am conceput un studiu în care s-a urmărit cunoașterea opiniilor reprezentanților din sistemul de sănătate cu privire la accesul redus la servicii publice de sănătate a populației rrome pe de o parte, și reprezentanții (liderii) etniei la nivel comunitar. 


\section{b. METODOLOGIE}

Pentru evaluare am utilizat o analiză calitativă bazată pe o metodologie și instrumente folosite în cadrul unei evaluări pilot în orașul Buftea.

\section{ANALIZA CALITATIVĂ}

În cadrul analizei calitative am elaborat un set de instrumente - ghiduri de interviu pentru categoriile de persoane incluse în evaluare, cu întrebări care să corespundă obiectivelor evaluării. Instrumentele au fost folosite la 150 persoane incluse în evaluare:

- Ghidul pentru interviul de grup (focus grup) cu membrii ai populației dezavantajate, inclusiv etnia rromă, din 4 comunități (Ștefăneștii de Jos, Buciumeni, Găneasa, Vidra). În fiecare din cele 4 comunități incluse în studiu am organizat un focus grup de 10-12 persoane provenind din comunitatea dezavantajată, inclusiv etnia rromă. Rezultatele au fost utilizate atât la elaborarea studiului privind serviciile de sănătate adresate rromilor, cât și la formularea recomandărilor finale.

- Ghid pentru interviul individual semistructurat cu decidenții din cadrul Autorității de Sănătate Publică (ASP) Ilfov, Casei Județene de Asigurări de Sănătate (CJAS) Ilfov; ghid pentru interviul semistructurat, medici de familie din comunitățile incluse în studiu și consilierul din Prefectura județului Ilfov din Biroul Județean pentru Rromi (BJR).

- Ghid pentru interviul individual semistructurat cu primarii din 4 localităţi având comunități dezavantajate, inclusiv etnia rromă (Buftea- Buciumeni, Stefăneștii de Jos, Vidra și Jilava).

Focus grupurile au fost efectuate în decurs de o săptămână, într-un mediu confortabil, controlat. Sesiunile au fost conduse de un investigator și o asistentă cu înregistrare audio. La sfârșitul fiecărei sesiuni s-a realizat o notă și cu aspectele limbajului non-verbal observate.

Interviurile: în medie au fost acordate în jur de 30 minute pentru fiecare interviu, cu o plajă de 35-40 minute. Conversațiile au fost înregistrate audio, intervievatorul a folosit notițe pentru a adăuga informații referitoare la limbajul non-verbal al respondenților; la sfârșitul interviului au fost alcătuite transcripturi după interviurile realizate și apoi au fost aplicate metodele de analiză calitativă specifice, urmărindu-se identificarea opiniilor comune ale respondenților, dar și particularități specifice.

\section{c. REZULTATE}

Evaluarea a urmărit în primul rând culegerea opiniilor persoanelor, membre ale comunitaților defavorizate, inclusiv etnia rromă, cu privire la starea de sănătate și accesul populației la servicii medicale în comunitățile luate în studiu. Întrebările care au urmărit culegerea acestor opinii au fost adresate tuturor categoriilor de persoane intervievate.

\section{A. SITUAȚIA RROMILOR ÎN RAPORT CU SISTEMUL INSTITUȚIONAL AL ASIGURĂRILOR SOCIALE DE SĂNĂTATE}

Toți subiecții intervievați apreciază că rromii trăiesc în condiții socio-economice evident deficitare, fapt ce are importanță în sfera stării de sănătate.

$\mathrm{Au}$ fost formulate și două direcții de evoluție probabilă a condițiilor socio-economice în care trăiesc:

1. o evoluție pozitivă - în cazul în care statul elaborează strategii și politici coerente în rezolvarea problemelor cu care se confruntă rromii; aceasta ar presupune rămânerea în sfera publică a serviciilor de sănătate și serviciilor sociale

2. în caz contrar privatizarea unor servicii publice - sănătatea, protecția socială, siguranța publică -sau ghidarea activității în funcție de eficiență și nu de eficacitate, adică centrarea eforturilor pe raportul mijloace -obiective și nu pe atingerea obiectivelor.

Din interviul cu decidenții reiese faptul că nu se cunoaște exact numărul persoanelor asigurate din județul Ilfov. La o populație de 300.100 locuitori, aproximativ $70 \%$ din populație are asigurări de 
sănătate, restul de 30 \% nu este asigurată. (E.G. CJAS Ilfov). Persoanele care nu dețin calitatea de asigurat se împart în două categorii: "un segment care este nepreocupat de a-și dobândi calitatea de asigurat, care realizează venituri și ar putea să o dobândească și un alt segment care nu va putea dobândi calitatea de asigurat decât dacă merge la primar să primească ajutor social datorită pierderii calității de asigurat sau pierderii locului de muncă, ajutorului de șomaj sau ajutorului social care au asociat dreptul la asigurarea medicalä“.

Situația rromilor: atât din intervievarea liderului rrom din Prefectură, cât și reprezentanților CJAS Ilfov, reiese că o mare parte din populația de rromi nu își plătesc contribuția la fondul asigurărilor de sănătate; majoritatea nu au un loc de muncă stabil și în cazul lor singura modalitate este să beneficieze de asistența socială. $\mathrm{O}$ dificultate apărută în calea înregistrării rromilor ca asigurați -în opinia reprezentanților CJAS Ilfov- o constituie lipsa actelor de identitate; din această cauză nu se pot angaja cu forme legale și nu pot dobândi calitatea de asigurat: “...există o categorie, nu știu cât de mare, care nu sunt în evidențta populației, persoane care nu au acte de identitate, nu au domiciliu, nu știu să apreciez procentul, 1-2\% din populație; aceasta este o categorie care consumă multe servicii de sănătate... " (E.G. CJAS Ilfov).

Această categorie de populație nu poate beneficia decât de pachetul minim de servicii dar, poate beneficia de venitul minim garantat (Legea 416/2002). Pe parcursul dobândirii acestor drepturi populația rromă întâmpină o serie de dificultăți. “ ... Cei fără acte pot fi trecuți pe o listă suplimentară a medicilor de familie din zona de domiciliu, urmând a beneficia de vaccinări și alte servicii de bază " (reprezentant CJAS Ilfov).

“...Alte probleme care afectează aplicarea legislației sunt diluarea responsabilității și lipsa informării asupra drepturilor și obligațiilor corelative, nou instituite, atât al celor activi în sistem cât și al beneficiarilor" (reprezentant ASPJ Ilfov). M.G, din cadrul ASPJ Ilfov, subliniază carența de informare legislativă atât a furnizorilor, cât și a beneficiarilor de servicii. Problema centralizării excesive este pusă în mod repetat de reprezentanții autorităților județene:”... deciziile cu privire la alocarea fondurilor trebuie luate la nivel bazal, cel mai jos posibil în funcție de situația specifică fiecărui judet,..."

La nivel de beneficiar, se identifică probleme de informare a drepturilor și obligațiilor asiguraților. Reprezentanții autorităților locale (primarii) intervievați acuză populația rromă aflată în această situație de ignoranță și lipsă de seriozitate în prestarea muncilor în folosul comunității pentru a putea beneficia de venitul minim garantat și implicit de asigurare medicală. Pe de altă parte, reprezentanții rromilor reclamă situații în care deși prestează muncă de câteva luni “...plățile întârzie, sau se dau parțial...”; "principalele probleme ale sistemului de asigurări de sănătate în ceea ce privește rromii sunt următoarele: lipsa de informare în ceea ce privește accesul la servicii de sănătate, lipsa de resurse pentru a accede la sistem şi probleme de atitudine și comportament generate de cultura sărăciei..." (V.O, Jilava)

În ceea ce privește excluderea informală -excluderea inclușilor (a rromilor de la servicii medicale) s-au putut identifica două categorii de factori:

1. factori generali care țin de organizarea și funcționarea sistemului de asistență medicală

2. factori specifici care țin de discriminare

Din prima categorie am putut sintetiza următorii factori generali, menționați de toți intervievații:

- costurile formale și informale ale asistenței medicale; în prezent a solicita servicii medicale pentru toată populația din România, presupune a “...cheltui mai mult sau mai puțin...”; e nevoie de bani pentru a achita "onorariul medicului“" care poate, în opinia respondenților, să influențeze calitatea actului medical, mai ales în cazul internării în spital

- calitatea serviciilor medicale a determinat reducerea accesării acestor servicii din partea populației 
- distribuția disproporționată a unităților ambulatorii și spitalicești care oferă servicii; serviciile de specialitate sunt absente în rural; de asemenea limitarea accesului populaţiei sărace inclusiv etnia rromă are loc și din cauza poziționării rezidențiale și geografice a serviciilor medicale

- dezechilibrul între partea curativă și preventivă “...la noi se tratează și se face prea puțină prevenție; populația este învățată să meargă la medic doar atunci când doare, nu acționează preventiv, pentru a plăti mai puțin" (C.M, medic de familie)

- dificultăţile medicilor de familie - mulți dintre medicii de familie intervievați recunosc existența problemelor birocratice și administrative față de relația cu pacientul sau actul medical: ”... medicul de familie se vede în postura celui mai dezavantajat salariat, incapabil să se opună unui sistem care lasă doar două alternative: să accepte inacceptabilul, sau să intre în somaj..."

- suprapopularea listelor în anumite localităti dezavantajate (de exemplu unul dintre medicii de familie din Vidra are 2300 pacienți asigurați, iar pe listele suplimentare are circa 850 rromi)

- lipsa de informare a pacienților “....sistemul este greoi, ar trebui să pierd prea mult timp explicând fiecărui pacient cum stau lucrurile...” (dr. E.C, Chitila, medic de familie)

- în majoritatea localităţilor medicii sunt navetiști, timpul real pentru consultații fiind diminuat; de multe ori medicii sunt concentrați în centrul comunei care deservește mai multe sate (în Găneasa există un sediu pentru cabinet medical care deservește 5 sate; medicul de familie face naveta la București în fiecare zi; cabinetul are un singur asistent medical. În Buciumeni - Buftea distanța între comunitatea de rromi și cel mai apropiat cabinet este de 6 kilometri)

- Numărul mic de asistente medicale - una din problemele identificate de medicii de familie intervievați, ceea ce îngreunează desfășurarea activității medicale

- În comunitățile din județul Ilfov nu există infrastructură și logistică necesare serviciilor de planificare familială

- Absența farmaciilor la nivel de comunitate este percepută mai grav decât lipsa medicului, dată fiind tendința de autoadministrare a unor tratamente "...mai bine ne înțelegem cu farmacista decât cu medicul sau cu asistenta; farmacista din comună ne mai dă și pe credit; este înțelegătoare ..." (localnic, Ștefăneștii de Jos)

Tabel I Atitudinea pacienților de etnie rromă față de medici în general

\begin{tabular}{|l|l|}
\hline \multicolumn{1}{|c|}{ ATITUDINI POZITIVE } & \multicolumn{1}{|c|}{ ATITUDINI NEGATIVE } \\
\hline Vorbeşte frumos & Vorbeşte urât \\
\hline Nu face diferenţă între oameni & Mă dă afară din cabinet - zice că o doare capul \\
\hline $\begin{array}{l}\text { Isşi respectă programul, uneori stă şi peste program } \\
\text { până termină consultațiile }\end{array}$ & Mi-a spus să-mi caut alt medic de familie \\
\hline Mă tratează şi mă sfătuieşte ce să fac în limba mea & Nu vine niciodată in sat \\
\hline Mă consultă & Nu mi-a dat tratamentul pe care l-am cerut \\
\hline Îmi dă tratament pentru copii şi lapte praf & $\begin{array}{l}\text { Când am cerut o scutire a zis că aşa suntem noi } \\
\text { țiganii, nu ne place munca }\end{array}$ \\
\hline Mi-a chemat şi salvarea & $\begin{array}{l}\text { A refuzat să-mi vadă copilul zicând că merge cu } \\
\text { situațiile }\end{array}$ \\
\hline M-a dus la spital cu maşina ei & Nu-mi dă lapte praf, zice că am sân \\
\hline Ne înțelege şi problemele din familie & \\
\hline Ne dă tratament mai bun ca la spital & \\
\hline Vorbeşte pe înțelesul nostru & \\
\hline De câte ori am avut nevoie m-a tratat şi sfătuit & \\
\hline $\begin{array}{l}\text { M-a consultat şi dacă nu am servici nici eu nici } \\
\text { soțul }\end{array}$ & \\
\hline
\end{tabular}




\section{B. PRINCIPALELE PROBLEME DE SĂNĂTATE CU CARE SE CONFRUNTĂ POPULAȚIA DEZAVANTAJATĂ, INCLUSIV RROMII}

Din analiza interviurilor efectuate reiese faptul că grupul etnic rom din județul Ilfov nu se confruntă cu probleme de sănătate esențial diferite de cele ale populației majoritare. Există totuși unele elemente specifice care au rezultat în urma studiului. Specialiștii în domeniul sănătătii care au fost intervievați au identificat anumite probleme de sănătate specifice care derivă din situația de sărăcie și cultura sărăciei: “...cele mai importante probleme de sănătate cred că provin din problemele sociale generale ale rromilor, adică mulți dintre ei nefiind asigurați sau fiind nomazi nu au medic de familie și nu-și fac controalele periodice ...” (reprezentant ASPJ Ilfov). În acest sens dr. C.D, medic pediatru, arată că “...începând de la vârsta de sugar și până la vârsta de adult ... pe prim-plan este patologia respiratorie, urmând patologia digestivă mai ales boala diareică infecțioasă la copil, parazitozele, iar mai apoi bolile cu transmitere sexuală...”. Este de asemenea menționată patologia TBC, cu mențiunea că nu poate fi invocată o preponderență a acesteia. De asemenea afecțiunile stomatologice au fost menționate de intervievați. Majoritatea acestor afecțiuni derivă din condițiile de locuit și igiena precară.

O serie de probleme sunt determinate de lipsa de organizare a vieții din punct de vedere al planificării familiale. În comunitățile de rromi tradiționale, fertilitatea nu este controlată; natalitatea ridicată în anumite comunități este asociată după anul 1990 cu o rată mare a avorturilor: “...eu cred că există pentru că au viața lor, spun asta pentru că se căsătoresc de mici deci au multe nașteri sau avorturi, deci sunt probleme deosebite. S,i cu fumatul sunt probleme de acest fel. Au probleme ginecologice, menopauza, deci nu sunt probleme specifice..." (asistenta medicală - Găneasa).

Nivelul ridicat al morbidității în comunitățile marginale fac extrem de dificilă intervenția serviciilor medicale și sociale. Apartenența la comunități marginalizate, sărace - înseamnă pe de o parte lipsa oportunităţilor și pe de altă parte însuşirea unui mod de viață adaptat sărăciei și excluziunii sociale. "...Sărăcia formează o cultură sau o subcultură - valori, norme, moduri de a gândi și simți, care modelează comportamentul indivizilor. Sărăcia nu se instalează doar prin lipsa mijloacelor de viață, dar și prin transmitere culturală în progresul socializării..." [2].

În cazul comunităților marginale de tipul Sintești - Vidra, Buciumeni-Buftea, Chitila-Săbăreni, Ganeasa-Cozieni, bolile și afecțiunile sunt determinate mai ales de condițiile de locuit sau alimentație decât de stilul de viață liber asumat.

Liderii rromilor intervievați aduc o completare în ceea ce privește calitatea vieții rromilor plasând în acest cerc vicios deficitul de educație.

Condițiile de viață ale comunităților de rromi sunt determinate nu doar de apartenența la o categorie socială marginală (lipsa accesului la utilități publice), ci și modul cum sunt utilizate resursele pe care le au "...igiena precară, aglomerarea locuinței sunt factori care depind de efortul individual..." (P.I, medic igienist ASPJ Ilfov).

Tuberculoza este în județul Ilfov, în special în comunitățile marginale, boala cu cea mai mare incidență (primul loc la nivel național). Subiecții intervievați apreciază că nu apar diferențe majore între pacienții rromi și cei de alte etnii decât în măsura în care comunitățile cu risc, sărace, sunt populate în majoritate cu rromi "... Condițiile precare de locuit, igiena necorespunzătoare, alimentația deficitară, sunt factori comuni predispozanți care înlătură barierele etnice..." (M.O, medic pneumoftiziolog). "...Un bolnav de TBC este o sursă de îmbolnăvire pentru ceilalți membri ai familiei sale în condițiile în care spațiul de locuit pentru 8-10 persoane din două sau trei generații se reduce la o cameră..." (M.M, asistent social Buftea).

Tot în cazul bolnavilor de TBC, sistemul medical deși asigură gratuitatea medicamentelor specifice, aceștia accesează greu aceste servicii datorită distanței și perioadei lungi de tratament. 


\section{Cauzele incidenței patologiei specifice din comunitățile dezavantajate, inclusiv etnia rromă}

- Cauze legate de cultura sărăciei

- Cauze relaționate cu sărăcia ca atare

Sărăcia manifestată în principal prin condiții de igienă precare, lipsa facilităților elementare: apă curentă, lumină, gaz, alimentație deficitară, periclitează starea de sănătate încă din perioada prenatală.

Specialiștii în sănătate publică intervievați apreciază că alimentația deficitară a mamei influențează negativ dezvoltarea armonioasă a copilului, iar diferitele infecții existente în organism datorită condițiilor neigienice de viață au același impact. În aceste condiții copilul este expus riscului de a se naște cu o serie de carențe (dr. L.M, medic epidemiolog ASPJ Ilfov). Specialiștii apreciază că fumatul în timpul sarcinii și formele de îngrijire tradițională ale femeilor gravide, lipsa controalelor periodice, pot conduce la o serie de disfuncții în organismul mamei, unele dintre ele putându-i pune în pericol viața (dr. V.I, medic O-G). Dacă se naște sănătos, copilul rrom beneficiază de o perioadă de siguranță relativă cât timp este alăptat. Odată cu încheierea acestei perioade urmează impactul dur al alimentației necorespunzătoare asupra sănătății copilului, ceea ce determină bolile digestive, subnutriția, distrofia, rahitismul, anemia (dr. S.D, medic pediatru).

Condițiile precare de igienă permit apariția parazitozelor și a bolilor infecțioase, în special respiratorii. Cultura sărăciei acționează ca sursă a multiplelor cauze a diverselor boli. “...Lipsa educației, atitudinea de neglijență în fața condițiilor improprii de locuit și alimentație, reticența în accesarea serviciilor de sănătate, modelele comportamentale deviante și stilul de viață neadaptat societății contemporane constituie de asemenea cauze a morbidității în comunitățile de rromi..." (dr. D.C, medic specialist sănătate publică ASPJ Ilfov).

Elementul cultural și educațional are repercursiuni severe începând cu primii ani de viață:“... ignoranța și nepăsarea părinților în fața vaccinărilor obligatorii pune în pericol sănătatea copiilor pe termen lung" (dr. S.D, medic de familie).

Liderii rromi intervievați includ în sfera culturii sărăciei și practica implicării copiilor în muncă începând cu 9-10 ani, determinând analfabetismul și abandonul școlar, proiectând astfel "...o educație insuficientă pe viitor, ceea ce reduce șansele romilor de a ieși din mizerie si sărăcie ...” (V.O, BJR Ilfov).

În opinia liderilor rromi intervievați, neînregistrarea în evidențele oficiale determină deteriorarea stării de sănătate a acestora mai ales cu implementarea sistemului de asigurări sociale de sănătate, “... rromii fără acte nu sunt angajați legal, nu au un venit minim garantat, nu beneficiază de servicii medicale ..." (P.M, lider Vidra).

\section{PROBLEMELE DE SĂNĂTATE ALE COPIILOR DIN COMUNITĂȚILE DEZAVANTAJATE, INCLUSIV ETNIA ROMĂ}

Subiecții intervievați au evidențiat în cadrul interviurilor faptul că în cazul copiilor romi nu există boli specifice, diferite de cele întâlnite la copiii grupului majoritar.

Liderii rromi intervievați consideră că pot apărea unele afecțiuni specifice referindu-se la perioada prenatală în care mamele nu au o alimentație corespunzătoare sau fumează “...multe mame nasc la 1718 ani, acest lucru însemnând un lucru negativ asupra sarcinii, iar condițiile de locuit și alimentație fac ca sănătatea copiilor romi să fie precară...” (M.P, Vidra).

Personalul medical intervievat crede că copiii rromi au starea de sănătate superioară datorită alimentației naturale prelungite “...dimpotrivă, de regulă familiile de romi își îngrijesc, țin la copil, față de populația generală; patologia e patologie spunem normală ...” (dr. I.B, medic de familie Vidra); “... sunt mai bine dezvoltați decât copiii noștri, la care alimentația naturală nu prea se practică ...” (dr. G.G. Buftea); “...deci ei merg foarte bine cât le ajunge alimentația naturală până în jur de 6-7 luni, după aproape toți devin distrofici, rahitici, deci cu probleme grave ...” (dr. P.C, Pantelimon). 
Specialiștii intervievați au identificat mai multe domenii de probleme de sănătate ale copiilor din comunitățile de rromi: boli respiratorii (bronșiolite, bronhopneumonii), digestive (enterocolite și parazitoze), anemia, rahitismul, afecțiuni dermatologice.

\section{Cauzele problemelor de sănătate specifice copiilor rromi}

Principalele cauze de îmbolnăvire a copiilor rromi se referă la condițiile socio-economice și la neglijența părinților, simptom al culturii sărăciei. Condițiile de alimentație și de îngrijire sunt apreciate de specialiști ca fiind inadecvate.

Părinții sunt considerați: "...refractari la indicațiile medicului de familie, la modul lor de ingrijire, la igiena sugarului; fug de spital ...nu respectă partea de prevenție rezultând carențe de fier, rahitism..." (dr. P.O, Jilava).

Condițiile socio-economice sunt considerate atât de specialiști cât și de liderii rromi intervievați, în mare măsură responsabile de incidența accentuată a anumitor boli.

Lipsa igienei alimentare, alimentația deficitară, lipsa mijloacelor de subzistență, au un impact direct asupra sănătății copiilor rromi.

De multe ori rromii spun că sunt discriminați și au reacții de adversitate față de medici, iar personalul medical invocă neglijența cronică a rromilor față de condițiile elementare de igienă, față de condițiile de prevenție prescrise și față de sfaturile primite. Acestea au fost relatate de specialiștii în sanătate, dar și de liderii rromi intervievați.

Prin nivelul scăzut de educație și stilul tradiționalist de viață, etnia rromă reprezintă un segment vulnerabil al societății, iar copiii rromi, elementul cel mai fragil al acesteia.

\section{PROBLEMELE DE SĂNĂTATE ALE POPULAȚIEI DE RROMI, ÎN COMPARAȚIE CU PROBLEMELE DE SĂNĂTATE ALE POPULAȚIEI GENERALE}

Atât în opiniile liderilor rromi intervievați, cât și în cele ale specialiștilor în probleme de sănătate publică, se arată că nu este corect să se vorbească de probleme de sănătate specifice populației de rromi. Poate fi vorba despre frecvența mai mare a unor boli în cadrul comunităților de rromi, dar aceasta e determinată de sărăcie și cultura sărăciei și nu de apartenența etnică ”...dacă ar fi români foarte săraci, ar fi în aceeași situație ca și rromii; dacă ne-rromii ar fi în aceeași situație economico socială ca și rromii, eu cred că ar avea aceleași probleme de sănătate...” (G.G, medic de familie, Buftea); "... etnia rromă este o grupare foarte grijulie cu starea ei de sănătate..." (dr. O.R, medic de familie, Buftea).

În județul Ilfov există diferențe de opinie între liderii populației rrome datorită ariei de raportare: consilierul BJR (d-l V.O.) susține că există probleme la nivel de județ. Faptul că mulți rromi se prezintă la medic doar în cazul apariției unei afecțiuni, conduce la agravarea stării de sănătate a acestora. Rromii au afecțiuni care necesită tratamente costisitoare, de exemplu diabetul sau afectiunile cardio-vasculare. Ei nu se tratează; ajung în stadii cronice, necesitând foarte mulți bani deseaba, sau oricum bani a căror cheltuire ar putea fi evitată. Un alt exemplu: unii rromi care nu își tratează bolile ajung în stadii cronice, care se transformă în handicapuri, obținând astfel dreptul la un însoțitor care câștigă salariul minim pe economie.

Din interviurile personalului medical a reieșit faptul că, în unele comunități, se întâlnește o incidență mai severă a unor boli determinate de abandonul copilului și a copiilor nevaccinați.

Fenomenul de abandon al copilului, în opinia specialiștilor în sănătate intervievați, implică costuri mari pentru societate: instituționalizarea copiilor fără a avea un impact direct asupra stării de sănătate a rromilor. În ceea ce privește situația nevaccinării copiilor rromi, aceasta are repercursiuni directe asupra stării lor de sănătate și chiar asupra sănătății comunitare, “...multe femei înțeleg foarte clar ce înseamnă vaccinul pentru copiii lor. Sunt femei care poate chiar nu înteleg, sau chiar nu vor să meargă. Dar nu cred că este ceva specific populației de rromi că nu acceptă vaccinul..." (L. O, Buftea). 
Cauzele acestor probleme de sănătate specifice sunt indentificate de subiecții intervievați ca fiind aceleași: condiții socio- economice precare și cultura sărăciei care le întreține. Opinia specialiștilor în domeniul sănătății care au fost intervievați este aceea că educația redusă a femeilor din populaţia rromă limitează accesul lor la informații și determină reticență față de vaccinări, de asemenea condițiile de alimentație precară, locuințe insalubre și igiena deficitară grefate pe o atitudine neglijentă și bazată pe o cultură tradiționalistă.

\section{E. CAUZELE ACCESULUI SCĂZUT AL RROMILOR LA SERVICII DE SĂNĂTATE}

Între cauzele de ordin general care concură la îngreunarea asistenței medicale pentru rromi, după cum reiese din interviurile aplicate, un loc central este ocupat de problemele de atitudine.

Medicii, pe de o parte, consideră că "....societatea le-a creat toate condițiile pentru a avea acces, totul depinde de ei...” (dr. G. O, medic de familia, Buftea), iar pe de altă parte împărtășesc opinia dr. M. C. ce afirmă că “...sunt foarte reticenți. Nu respectă schemele de tratament. Nu respectă programarea la medic pentru examenele de bilanț...”.

Din interviurile realizate rezultă ca unii medici afirmă că au dificultăți de relaționare cu rromii, acuzând o ținută marcată de lipsa de igienă și o atitudine pe care ei o consideră nerespectuoasă, revendicativă.

Liderii romi intervievați afirmă că “...rromii de obicei sunt foarte săraci, și în același timp au o stare emotională negativă. Situația tipică decurge astfel: ai mei merg o dată, de două ori și nu sunt primiți, a treia oară când merg fac scandal, și de aici apare conflictul..."; "...merg cu un miros mai interesant la medic..." (V. O, Jilava).

\section{Cauze care derivă din cadrul funcțional al legii 95/2006}

În interviul realizat de dr. G. E. (CJAS Ilfov), acesta apreciază “...mulți dintre rromi nu se încadrează în legea actuală; o proporție de $20 \%$ din rromi nu beneficiază de asigurare de sănătate fie din cauză că nu au acte, fie datorită faptului că nu au un loc de muncă..."

Lipsa informației cu privire la cadrul legal care reglementează asigurările sociale de sănătate în cadrul comunităților de rromi e identificată de către liderii acestora ca una din cauzele care îngreunează accesul la asistența medicală: “...sunt mulți care nu știu; dacă înainte rromii nu beneficiau de servicii de sănătate în condiții normale, în prezent rromii nu beneficiază aproape deloc, din cauza politicii...” (V. O, Jilava).

Perspectiva medicilor aduce argumente în plus opiniei potrivit căreia rromii sunt dezavantajați în actualul sistem: “...pacienții sunt foarte reticenți, iar medicii au dreptul să nu-i înscrie pe listă...” (dr. B. N, Vidra).

În contractul cadru și în normele de aplicare a acestuia se specifică foarte clar că dacă nu se respectă indicațiile medicului, acesta are posibilitatea să renunțe la pacientul de pe listă.

\section{Cauze care derivă din statutul socio-economic şi educațional-cultural al rromilor}

Reglementările legislative relaţionează statutul de asigurat de obținerea unui venit minim garantat. Neangajarea și șomajul ridicat în cadrul comunității rome determină accesul scăzut al acesteia la sistemul de sănătate. Soluția prestării muncii în folosul comunității (legea 416/2002) vine în sprijinul celor care nu obțin nici un venit, spre a le asigura venitul minim garantat.

Lipsa actelor de identitate și sărăcia accentuată întreținută prin cultura sărăciei, se adaugă la cauzele care îngreunează accesul la asistența medicală.

Educația deficitară în rândul populației rrome conduce la pătrunderea greoaie a informației în aceste grupuri, lipsa informației îngreunând accesul rromilor la sistemul de sănătate.

Dr. B. C. (ASPJ Ilfov) menționează principalele probleme ale sistemului de asigurări de sănătate cu incidență asupra rromilor: "...lipsa de informare în ceea ce privește accesul la serviciile de sănătate, lipsa de resurse pentru a accesa acest sistem și problemele de atitudine și comportament generate de cultura sărăciei...”. 


\section{Referințe}

1. *** Raportul național al dezvoltării umane, România - 1998, inițiat de PNUD, realizat de Academia Română, Editura Expert, Bucureşti, 1998

2. ***UNICEF, DPC. Situatia copilului în familiile de romi, în Zamfir, E; Tolstobrach, N (consilieri ştiinţifici), Situatia copilului si a familiei în România, Bucuresti,1997

3. Culic, I, Horvath, I, Lazar, M. Etnobarometru - relatii interetnice în România, Centrul de Resurse pentru Diversitate Etnoculturala, Risoprint, Cluj-Napoca

4. Overetveit, J. Health service quality; An introduction to quality methods for health services, Oxford, 1992.

5. Miftode, D. Metodologia sociologică. Metode si tehnici de cercetare sociologice, 1995

6. Shaw, I. Qalitative evaluation, 1999

7. Silverman, D. Communication and Medical Practice, 1987

8. Silverman, D. Interpreting Qualitatve Data, 1993

9. Silverman, D. Qualitative Researche, 1997

10. Strauss A, Corbin. Basics of Qualitative Researche, 1994 